\title{
Pembangunan Perangkat Lunak Game Maker X dengan Mengimplementasikan Teknik Reflection dan...
}

Conference Paper · September 2011

\section{CITATIONS}

0

1 author:

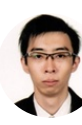

Oscar Karnalim

Universitas Kristen Maranatha

20 PUBLICATIONS 15 CITATIONS

SEE PROFILE
READS

10

Some of the authors of this publication are also working on these related projects:

Project Virtual Alumni Tracer View project

Project Java Archive Retrieval System View project 


\title{
PEMBANGUNAN PERANGKAT LUNAK GAME MAKER X DENGAN MENGIMPLEMENTASIKAN TEKNIK REFLECTION DAN OBJECT REUSE
}

\author{
Oscar Karnalim \\ Fakultas Teknologi Informasi, Universitas Kristen Maranatha \\ Jl. Prof. drg. Suria Sumantri no 65, Bandung 40164 \\ oscar.karnalim@itmaranatha.org
}

\begin{abstract}
ABSTRAK
Bidang game development yang semakin berkembang pesat menarik minat masyarakat luas untuk menciptakan game buatannya sendiri. Namun minat tersebut sukar terealisasikan karena pembangunan sebuah game menghabiskan banyak waktu dan mewajibkan pembuatnya menguasai konsep -konsep dasar pembuatan game secara mendalam. Dengan adanya perangkat lunak game maker, pengguna tidak perlu membangun semua bagian game dari awal dan menguasai konsep-konsep dasar pembuatan game secara mendalam. Pada penelitian ini, akan dibangun sebuah perangkat lunak game maker dengan mengimplementasikan teknik reflection dan object reuse. Reflection adalah salah satu teknik pemrograman yang memungkinkan suatu objek merefleksikan informasi mengenai dirinya sendiri. Object reuse adalah salah satu teknik pemrograman dimana sistem akan menggunakan kembali objek yang telah digunakan sebelumnya. Kedua teknik tersebut diimplementasikan pada perangkat lunak ini guna menciptakan sistem game maker yang dinamis dan efisien. Perangkat lunak ini telah berhasil dibangun dengan paradigma berorientasi objek dan telah berhasil dimodelkan untuk memanipulasi game $\mathrm{X}$.
\end{abstract}

Keywords: game maker, code generator, object reuse, reflection.

\section{PENDAHULUAN}

Bidang game development yang semakin berkembang pesat menarik minat masyarakat luas untuk menciptakan game buatannya sendiri. Namun minat tersebut sukar terealisasikan karena pembangunan sebuah game menghabiskan banyak waktu dan mewajibkan pembuatnya menguasai konsep-konsep dasar pembuatan game secara mendalam. Dengan adanya perangkat lunak game maker, pengguna tidak perlu membangun semua bagian game dari awal dan menguasai konsepkonsep dasar pembuatan game secara mendalam. Pengguna hanya perlu mengerti cara penggunaan perangkat lunak game maker tersebut [1]. Game maker adalah sebuah perangkat lunak yang mempermudah penggunanya untuk membangun sebuah game dengan batasan tertentu [2].

Perangkat lunak game maker yang dibangun pada penelitian ini akan menerapkan teknik object reuse dan reflection. Reflection adalah salah satu teknik pemrograman yang memungkinkan suatu objek merefleksikan informasi mengenai dirinya sendiri Object reuse adalah salah satu teknik pemrograman dimana sistem akan menggunakan kembali objek yang telah digunakan sebelumnya Kedua teknik tersebut diimplementasikan pada perangkat lunak ini guna menciptakan sistem game maker yang dinamis dan efisien.

Dengan menggunakan perangkat lunak ini, pengguna dapat membangun sebuah game $\mathrm{X}$ dengan tampilan, alur cerita, kecerdasan buatan, kemampuan, efek, status dan event area sesuai keinginannya. Game $\mathrm{X}$ adalah sebuah game $2 \mathrm{D}$ bergenre wargames yang dibangun oleh penulis sebagai hasil keluaran dari perangkat lunak game maker ini.

\section{LANDASAN TEORI}

Bagian ini akan membahas mengenai game maker, code generator, reflection, dan object reuse.

\subsection{Game maker}

Game maker adalah sebuah perangkat lunak yang mempermudah penggunanya untuk membangun sebuah game tertentu dengan batasan tertentu. Dengan menggunakan perangkat lunak ini, pengguna dapat membangun game tertentu sesuai dengan keinginannya tanpa memerlukan kemampuan pemrograman yang mendalam. Pengguna hanya perlu memahami cara penggunaan perangkat lunak game maker.

Game maker menyediakan antarmuka dan methodmethod yang mempermudah penggunanya dalam membangun sebuah game sehingga pengguna tidak perlu membangun semua kode perangkat lunak game dari awal. Pengguna juga dapat memasukkan gambar dan suara sebagai resource game ciptaannya [2].

\subsection{Code Generator}

Code generator adalah sebuah perangkat lunak yang mempermudah penggunanya dalam membangun kode perangkat lunak lain. Proses pada code generator memerlukan dua bagian penting yaitu template dan model data. Template adalah bagian dokumen yang menjelaskan pola struktur output. Template memiliki field - field 
untuk menentukan letak posisi data yang akan dimasukkan. Model data adalah format penempatan data dalam template.

Code generator tidak hanya memasukkan model data ke dalam sebuah template melainkan juga menciptakan file - file lain yang diperlukan untuk membangun perangkat lunak tersebut. Semakin luas cakupan dari sebuah code generator, semakin umum bentuk template yang ada sehingga semakin menyulitkan pengguna dalam mengoperasikannya [3].

\subsection{Reflection}

Reflection adalah salah satu teknik pemrograman dimana suatu objek dapat merefleksikan informasi mengenai dirinya sendiri. Teknik ini mampu memanipulasi struktur, atribut, dan method pada suatu kelas atau objek.

Reflection dapat memonitor pelaksanaan suatu lampiran kode dan dapat memodifikasi kode program tersebut secara otomatis. Reflection biasanya digunakan dalam pemrograman beorientasi objek yang dinamis [4].

\subsection{Object Reuse}

Object reuse adalah salah satu teknik pemrograman dimana sistem akan menggunakan kembali objek yang telah digunakan sebelumnya. Teknik ini cocok digunakan pada perangkat lunak real-time yang membentuk objek sejenis dalam jumlah banyak. Object reuse biasanya digunakan untuk menghilangkan delay yang muncul akibat pembentukan objek saat perangkat lunak berjalan.

Object reuse juga akan mengurangi delay yang disebabkan oleh garbage collector karena setiap objek yang sudah terpakai tidak akan langsung dibuang. Garbage collector adalah fitur bahasa pemrograman Java yang berfungsi untuk membuang objek-objek tidak terpakai pada memori secara otomatis. Setiap kali garbage collector berfungsi, sistem akan menghentikan semua proses yang sedang berjalan sehingga akan menimbulkan delay. Teknik ini secara tidak langsung memindahkan pekerjaan garbage collector ke perangkat lunak sehingga perangkat lunak perlu menangani siklus penggunaan objek objek yang ada [5].

\section{ANALISA}

Perangkat lunak game maker X merupakan sebuah perangkat lunak game maker yang mempermudah penggunanya membangun game X. Game X adalah sebuah game $2 D$ bergenre wargames yang dibangun oleh penulis sebagai hasil keluaran dari perangkat lunak game maker ini.
Game $\mathrm{X}$ adalah game $2 D$ yang mengambil skenario di dunia monster. Pada awal game, pemain akan diberikan sejumlah uang untuk membeli pasukan dan barang. Setelah itu, pemain akan dihadapkan pada serangkaian stage peperangan yang bersifat real-time.

Pada setiap stage, pemain dapat memanggil pasukan, meningkatkan status pasukan, menarik mundur pasukan, dan menggunakan barang. Pemain hanya dapat melakukan aksi jika ia memiliki poin pertarungan yang cukup. Poin pertarungan akan meningkat seiring berjalannya waktu pada stage tersebut.

Setiap kali pemain memenangkan suatu stage, pemain akan mendapatkan uang yang dapat digunakan untuk membeli barang ataupun pasukan. Pemain juga dapat menyimpan dan meload data game.

Perangkat lunak game maker $\mathrm{X}$ menggabungkan konsep game maker dan code generator dimana pengguna tidak hanya dapat membuat game $\mathrm{X}$ dengan mudah, namun juga dapat memasukkan kode program buatannya sendiri. Pengguna dapat mendesain kecerdasan buatan, skill karakter, status karakter, dan kondisi pertarungan yang ada sesuai dengan keinginannya. Pengguna juga dapat memasukkan gambar dan suara sebagai resource game dimana masukan gambar berbentuk sprite berformat PNG dan masukan suara berformat WAV.

Pengguna dapat membentuk objek - objek game dengan mengisi field - field yang telah disediakan pada perangkat lunak. Jenis objek tertentu mewajibkan penggunanya untuk menambahkan kode program guna menciptakan efek objek yang bervariasi. Perangkat lunak akan menghasilkan kode kelas berdasarkan data pada field - field tersebut dan mengkompilenya secara otomatis.

Setiap objek pasukan yang terbentuk akan mengimplementasikan kecerdasan buatan finite state machine dan pathfinding menggunakan algoritma $A^{*}$. Pengguna juga dapat memodifikasi state kecerdasan buatan sesuai keinginannya dan mengatur bobot node yang akan digunakan dalam algoritma $A^{*}$.

Reflection akan diimplementasikan pada perangkat lunak ini untuk memanipulasi dan menampilkan atribut status setiap pasukan yang bervariasi. Reflection yang diterapkan terbatas pada tipe data primitif dan String saja.

Game X akan mengimplementasikan konsep object reuse untuk meminimalisir delay yang disebabkan oleh proses pembentukan objek dan proses garbage collector. 
Sistem akan membentuk beberapa objek game pada awal permainan dengan atribut kosong. Ketika sistem memerlukan objek - objek tersebut, sistem hanya perlu mengisi nilai atribut pada objek - objek yang sudah dibentuk sebelumnya. Ketika suatu objek selesai digunakan, objek tidak akan dibuang melainkan disimpan pada sistem untuk digunakan kembali. Apabila jumlah objek yang dibutuhkan melebihi jumlah objek yang ada, sistem akan membentuk kembali objek - objek sejenis. Sistem akan menyesuaikan kembali jumlah objek yang dimilikinya ketika satu stage game selesai dimainkan.

Sistem memiliki sebuah kelas statis yang berperan sebagai pusat seluruh data dan proses. Kelas ini memiliki dua method yang mengimplementasikan object reuse yaitu method returnObject yang berfungsi untuk mengembalikan objek yang sudah terpakai pada kelas ini, dan method get yang berfungsi untuk mengambil objek baru dari kelas ini.

Setiap objek yang menerapkan konsep object reuse akan memiliki konstruktor kosong dan method init. Method init akan berperan sebagai pengganti constructor untuk menginisialisasi nilai atribut pada objek. Proses pengisian nilai atribut pada objek tidak dilakukan pada constructor melainkan pada method init agar proses inisialisasi nilai atribut pada objek dapat dilakukan berulang ulang.

Perangkat lunak ini akan menghasilkan keluaran berupa proyek game yang dapat dimodifikasi dikemudian hari. Pengguna juga dapat memainkan game yang telah dibangun pada game project tersebut. Perangkat lunak ini akan dibangun menggunakan bahasa pemrograman Java dengan media penyimpanan XML.

\section{IMPLEMENTASI DAN PENGUJIAN}

Perangkat lunak game maker $\mathrm{X}$ yang dibangun pada penelitian ini merupakan sebuah perangkat lunak yang mempermudah penggunanya membangun game $\mathrm{X}$. Perangkat lunak ini akan menyimpan informasi proyek game pada file XML.

Perangkat lunak ini memiliki file masukan ProjectFile.xml yang menyimpan list proyek game yang ada dan File keluaran Dataxml yang menyimpan data game. File Data.xml akan menentukan proses jalannya game. Perangkat lunak ini memiliki beberapa fitur utama yaitu, membangun proyek game baru, mengubah proyek game, menghapus proyek game, memainkan proyek game dan keluar. Use case perangkat lunak dapat dilihat pada gambar 1 .

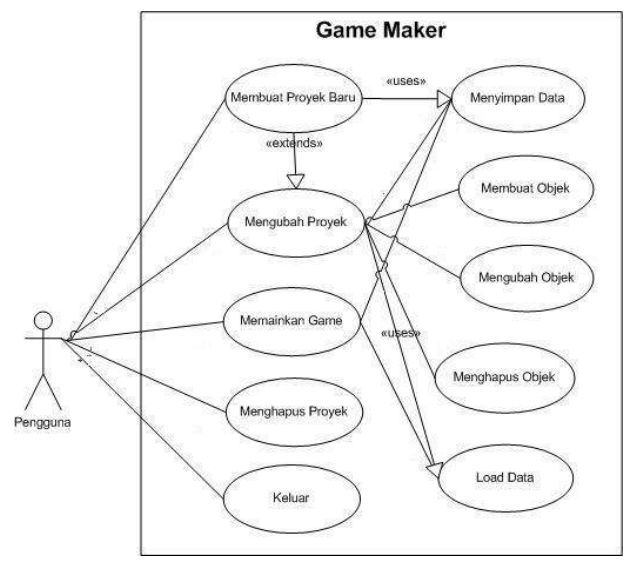

Gambar 1. Use case perangkat lunak

Antarmuka perangkat lunak diawali dengan antarmuka pemilihan proyek game. Pada antarmuka ini, pengguna dapat memanipulasi proyek game seperti menambah, mengubah, dan menghapus proyek game. Antarmuka pemilihan proyek game dapat dilihat pada gambar 2 .

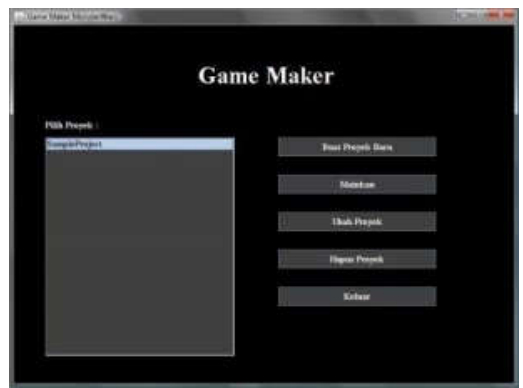

Gambar 2. Antarmuka pemilihan proyek game

Jika pengguna memilih untuk menambah proyek baru, sistem akan meminta pengguna memasukkan nama proyek game. Jika nama proyek tersebut valid, Sistem akan membangun sebuah direktori dengan nama proyek tersebut. Direktori tersebut terdiri dari 3 bagian, yaitu direktori Image untuk menyimpan resource gambar, direktori Sound untuk menyimpan resource audio, dan Data.xml yang menyimpan informasi game.

Setelah pengguna membuat proyek baru atau memilih fitur ubah proyek, Sistem akan menampilkan antarmuka manipulasi proyek game. Pada antarmuka ini, pengguna dapat mendesain ukuran layar game, jeda penggambaran, latar belakang antarmuka utama, musik antarmuka utama dan objek - objek pada game. Apabila antarmuka tersebut merupakan hasil dari fitur ubah proyek, Field - field pada antarmuka ini akan berisi data proyek game yang akan diubah. Antarmuka manipulasi proyek game dapat dilihat pada gambar 3. 


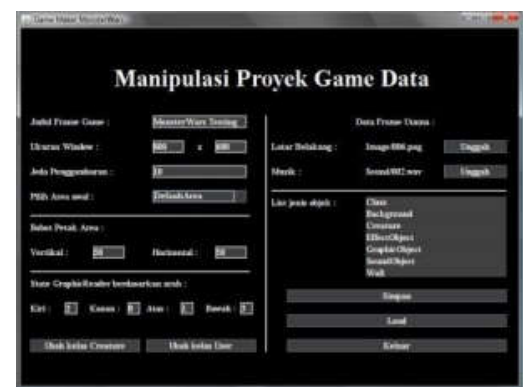

Gambar 3. Antarmuka manipulasi proyek game

Apabila pengguna memilih untuk memanipulasi jenis objek Class, Sistem akan menampilkan antarmuka manipulasi kelas. Sistem akan menampilkan data semua kelas yang pernah dibentuk dalam proyek ini.

Jika pengguna memilih salah satu nama kelas pada list, sistem akan menampilkan nama kelas dan kode program kelas tersebut pada field - field yang ada. Pengguna dapat memilih untuk menyimpan, menghapus, atau meng-compile kelas tersebut. Pengguna juga dapat membuat kelas baru dengan cara memilih jenis kelas yang ingin dibentuk pada combobox yang tersedia. Sistem akan meminta pengguna untuk memasukkan nama kelas. Jika nama kelas tersebut valid, sistem akan menampilkan template kelas terkait pada textarea yang ada. Template tersebut tidak hanya berisi template kelas, tapi juga keterangan mengenai cara membuat kode kelas tersebut. Antarmuka ketika pengguna memilih template kelas dapat dilihat pada gambar 4 .

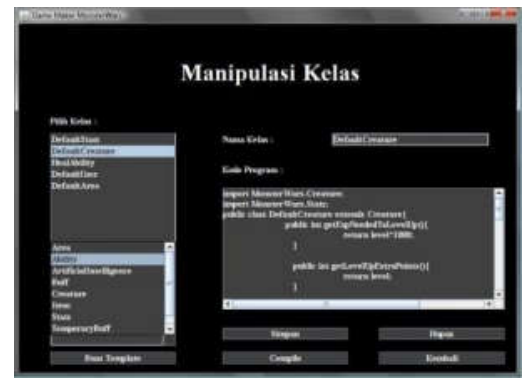

Gambar 4. Antarmuka manipulasi kelas

Apabila pengguna memilih template kelas Area, User, atau ArtificialIntelligence, pengguna dapat memilih untuk membangun kode tersebut dengan antarmuka manipulasi kelas atau antarmuka khusus. Jika pengguna memilih antarmuka khusus, pengguna hanya perlu mengisi field-field yang telah disediakan lalu sistem akan menghasilkan kode kelasnya secara otomatis.

Antarmuka pembangunan area memiliki fitur tambahan bernama tinjau area dimana pengguna dapat membangun objek-objek dalam area secara otomatis hanya dengan memilih koordinat matriks dan jenis objek yang diinginkan. Antarmuka peninjauan objek-objek dalam area dapat dilihat pada gambar 5 .

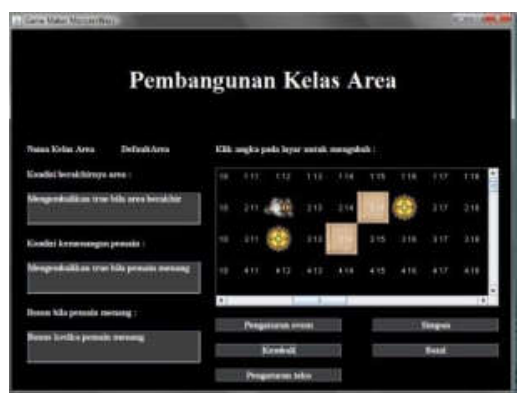

Gambar 5. Antarmuka manipulasi area

Apabila pengguna memilih untuk memanipulasi jenis objek selain Class, Sistem akan menampilkan antarmuka manipulasi objek sesuai dengan jenis objek yang dipilih. Antarmuka manipulasi objek Creature menggunakan teknik reflection untuk menampilkan semua atribut objek Creature yang sedang dipilih. Antarmuka manipulasi objek Creature dapat dilihat pada gambar 6.

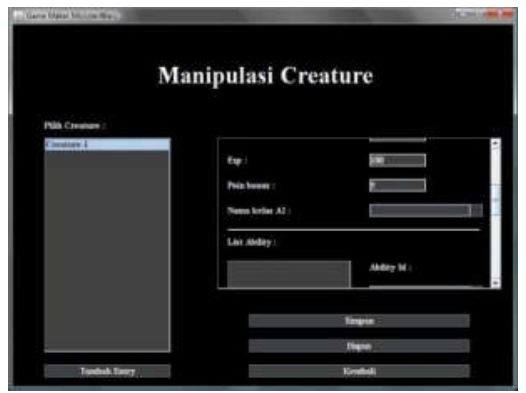

Gambar 6. Antarmuka manipulasi objek creature

Jika pengguna ingin memanipulasi resource gambar atau suara, pengguna harus memilih fitur manipulasi GraphicObject atau fitur manipulasi SoundObject. GraphicObject merupakan kelas yang menangani resource gambar, sedangkan SoundObject merupakan kelas yang menangani resource suara.

Pengguna dapat menambahkan resource gambar atau suara dengan cara mengunggah file tersebut ke sistem. File yang dapat diproses oleh sistem hanyalah file gambar berformat PNG dan file suara berformat WAV. Setelah pengguna memilih file, sistem akan mengecek apakah file tersebut berada di dalam atau di luar direktori proyek game. Apabila file tersebut berada diluar direktori, Sistem akan menyalin file tersebut kedalam direktori. Antarmuka manipulasi resource gambar dapat dilihat pada gambar 7 . 


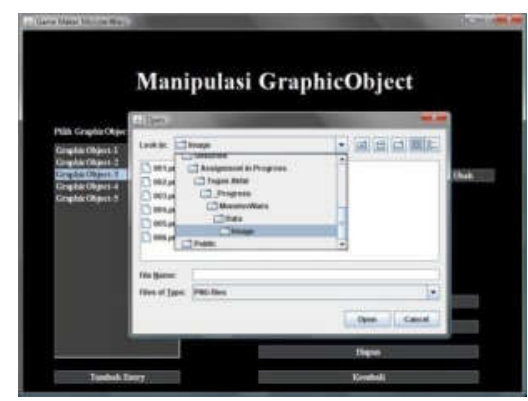

Gambar 7. Antarmuka manipulasi resource gambar

Jika pengguna memilih untuk memainkan game, sistem akan mengalihkan pengguna pada antarmuka utama game $\mathrm{X}$. Tampilan antarmuka dan sistem pada game bergantung pada proyek game yang telah dibuat sebelumnya.

Jika pengguna memilih untuk menghapus proyek game, sistem akan menghapus semua data proyek game terpilih. Jika pengguna memilih untuk keluar, sistem akan dihentikan secara otomatis.

Pada antarmuka utama game $\mathrm{X}$, pengguna dapat memainkan game dengan data yang sudah ada atau dengan data baru. Contoh antarmuka utama game $\mathrm{X}$ dapat dilihat pada gambar 8 .

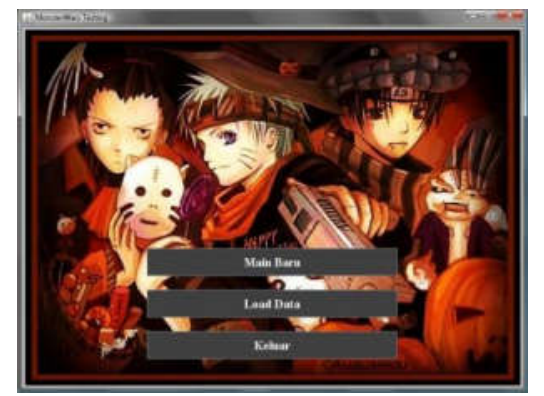

Gambar 8. Contoh antarmuka utama game X

Setelah pemain memilih data yang akan digunakan, Sistem akan membangun sejumlah objek game dan menampilkan antarmuka persiapan sebelum berperang. Jumlah objek game yang dibangun bergantung pada memori Java virtual machine komputer dimana sistem akan menggunakan sepertiga bagian dari memori tersebut untuk menyimpan objek - objek game. Pada antarmuka ini, pemain menyimpan data, meload data, dan membeli barang atau pasukan. Contoh antarmuka persiapan sebelum berperang game $\mathrm{X}$ dapat dilihat pada gambar 9.

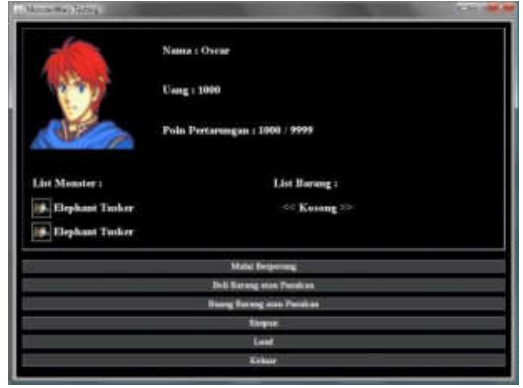

Gambar 9. Contoh antarmuka persiapan sebelum berperang game $\mathrm{X}$

Pemain dapat membeli barang atau pasukan pada antarmuka pembelian barang atau pasukan. Antarmuka ini dapat diakses dari antarmuka persiapan sebelum berperang dengan cara menekan tombol beli barang atau pasukan. Contoh antarmuka pembelian barang atau pasukan game $\mathrm{X}$ dapat dilihat pada gambar 10 .

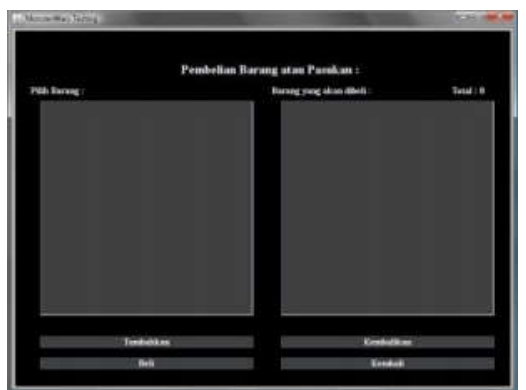

Gambar 10. Contoh antarmuka pembelian barang atau pasukan game $\mathrm{X}$

Pemain dapat memulai stage dengan cara menekan tombol mulai berperang pada antarmuka persiapan sebelum berperang. Pada saat peperangan berlangsung, sistem akan menggunakan objek objek game yang telah dibangun sebelumnya. Jika jumlah objek game jenis tertentu tidak mencukupi, sistem akan membangun kembali sejumlah objek game tersebut. Contoh antarmuka stage game $\mathrm{X}$ dapat dilihat pada gambar 11 .

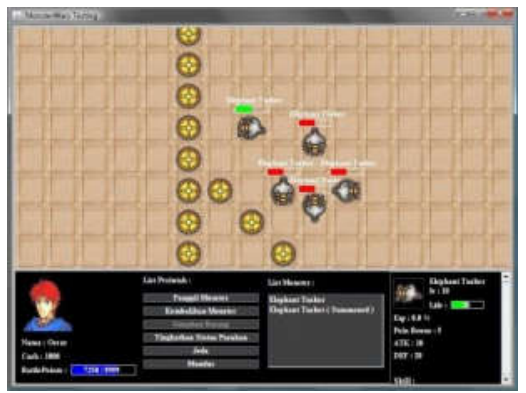

Gambar 11. Contoh antarmuka stage game X

Pada saat peperangan berlangsung, sistem terkadang akan memunculkan notifikasi yang berisi informasi mengenai alur cerita atau kondisi peperangan. Kemunculan notifikasi ini bergantung 
pada data proyek game yang telah dibuat sebelumnya. Contoh antarmuka munculnya notifikasi pada saat berperang dapat dilihat pada gambar 12.

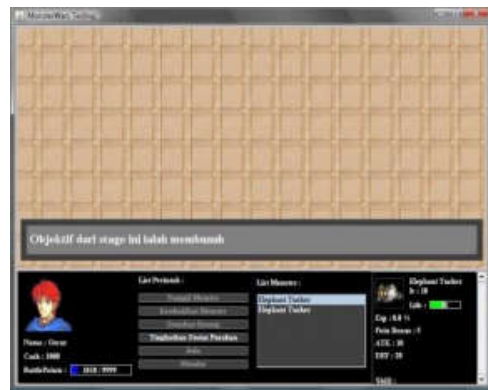

Gambar 12. Contoh antarmuka munculnya notifikasi pada saat berperang

Pada saat peperangan selesai, sistem akan menyesuaikan jumlah objek game yang ada guna menghindari pemakaian memori berlebih. Apabila pemain memenangkan peperangan, sistem akan mengarahkan pemain pada antarmuka persiapan sebelum peperangan stage selanjutnya atau kembali pada menu utama jika stage yang dimenangkan adalah stage terakhir. Apabila pemain kalah, sistem akan mengarahkan pemain pada menu utama.

\section{KESIMPULAN}

Berdasarkan hasil pembangunan perangkat lunak ini, dapat diambil beberapa kesimpulan yaitu:

1. Perangkat lunak game maker telah berhasil dibangun dengan paradigma berorientasi objek.

2. Perangkat lunak game maker mampu membuat game $\mathrm{X}$ yang dapat dimainkan.

3. Antarmuka perangkat lunak game maker telah berhasil dimodelkan untuk memanipulasi proyek game X.

\section{DAFTAR PUSTAKA}

[1] Mendez, Danilo, "SmartCode-An Open Source Code Generator", tersedia pada http:/www.codeproject.com/KB/dotnet/Smar tCode-Code_Generation.aspx diakses pada tanggal 29 Mei 2010.

[2] Overmars, Mark., "Designing Game with Game Maker", tersedia pada http://www.gamemaker.nl/ diakses pada tanggal 20 Desember 2010.

[3] Codejen team, 2009,, "Code Generator User Guide", Codejen.

[4] Sobel, Jonathan M, Daniel P. Friedman, 1996, "An Introduction to Reflection-Oriented Programming", Computer Science Department, Indiana University.

[5] Al-Jaroodi, Jameela, Nader Mohamed, 2005, "Object-Reuse for More Predictable RealTime Java Behavior", Stevens Institute of Technology. 